Do plants modulate biomass allocation in

\section{response to petroleum pollution?}

\author{
Ming Nie ${ }^{1,2}$, Qiang Yang ${ }^{1}$, Li-Fen Jiang ${ }^{1}$, \\ Chang-Ming Fang ${ }^{1}$, Jia-Kuan Chen ${ }^{1,2}$ \\ and $\mathbf{B o} \mathbf{L i}^{1,2, *}$
}

${ }^{1}$ Key Laboratory for Biodiversity Science and Ecological Engineering, Institute of Biodiversity Science, Fudan University, Shanghai 200433, People's Republic of China

${ }^{2}$ Centre for Watershed Ecology, Institute of Life Science and Key Laboratory of Poyang Lake Environment and Resource Utilization, Nanchang University, Nanchang 330031, People's Republic of China *Author for correspondence (bool@fudan.edu.cn).

Biomass allocation is an important plant trait that responds plastically to environmental heterogeneities. However, the effects on this trait of pollutants owing to human activities remain largely unknown. In this study, we investigated the response of biomass allocation of Phragmites australis to petroleum pollution by a ${ }^{13} \mathrm{CO}_{2}$ pulse-labelling technique. Our data show that plant biomass significantly decreased under petroleum pollution, but the root-shoot ratio for both plant biomass and ${ }^{13} \mathrm{C}$ increased with increasing petroleum concentration, suggesting that plants could increase biomass allocation to roots in petroleum-polluted soil. Furthermore, assimilated ${ }^{13} \mathrm{C}$ was found to be significantly higher in soil, microbial biomass and soil respiration after soils were polluted by petroleum. These results suggested that the carbon released from roots is rapidly turned over by soil microbes under petroleum pollution. This study found that plants can modulate biomass allocation in response to petroleum pollution.

Keywords: biomass allocation; ${ }^{13} \mathrm{CO}_{2}$ pulse-labelling; petroleum pollution; photosynthesis; Phragmites australis

\section{INTRODUCTION}

Biomass allocation of plants is an important trait that constantly senses environmental changes (Hermans et al. 2006; Berendse \& Moller 2009). Many studies have suggested that plants can adaptively respond to belowground stresses by altering biomass allocation to the belowground parts, to alleviate the stresses in a manner that optimizes the capture of soil nutrients and maximizes plant growth rate (Bonifas et al. 2005; Mahoney \& Swanton 2008). However, the impacts of pollutants on plants' biomass allocation remain largely unknown. Understanding biomass allocation of plants in response to environmental pollution will enable us to better understand the mechanisms by which plants respond adaptively to an imbalance of resources and

Electronic supplementary material is available at http://dx.doi.org/ $10.1098 /$ rsbl.2010.0261 or via http://rsbl.royalsocietypublishing.org. predict what plant features increase their fitness under environmental changes.

Petroleum pollution, as an important global change, has broadly threatened the environments of plants owing to human activities (Kingston 2002; Peterson et al. 2003). In China, for example, the area for petroleum exploration accounts for 3 per cent of the total land area and about 60 million tons of petroleum on average enters the soil every year (Liu et al. 2007). While several studies have documented that petroleum pollution has negative effects on plant growth, little is known about how biomass allocation of plants responds to petroleum pollution (Dowty et al. 2001; Culbertson et al. 2008). In this paper, we conducted a controlled study with the common plant Phragmites australis of how plants alter biomass allocation in response to varying petroleum concentrations. Phragmites australis was selected because of its tolerance to petroleum pollution and important ecosystem functions (Engloner 2009; Nie et al. 2009). According to a simple model of flux and fate of carbon from photosynthesis (electronic supplementary material, figure S1) (Kuzyakov et al. 1999), the ${ }^{13} \mathrm{C}-\mathrm{CO}_{2}$ pulse-labelling technique was used to investigate the allocation of photosynthetically fixed carbon in response to petroleum pollution.

\section{MATERIAL AND METHODS}

Phragmites australis seeds were collected from the Shengli oilfield in Shandong Province, China $\left(37^{\circ} 33^{\prime} \mathrm{N} ; 118^{\circ} 30^{\prime} \mathrm{E}\right)$. The topsoil $(0-20 \mathrm{~cm})$ was sampled from a site with no history of previous petroleum pollution in the National Nature Reserve of the Yellow River Delta near the oilfield (Nie et al. 2009). Three treatments of petroleum-polluted soils were designated by mixing the soil with crude oil from the Shengli oilfield, i.e. control $\left(0 \mathrm{mg} \mathrm{kg}^{-1}\right)$, low pollution $\left(6000 \mathrm{mg} \mathrm{kg}^{-1}\right)$, and high pollution $\left(12000 \mathrm{mg} \mathrm{kg}^{-1}\right)$. After emergence of the first euphylla, one seedling of $P$. australis was transferred to the centre of a pot filled with $228.15 \mathrm{~g}$ of prepared soil (dry weight). A total of 27 pots (three treatments $\times$ three replicates $\times$ two incubation times $(24 \mathrm{~h}$ or $72 \mathrm{~h}$ after the initiation of pulse labelling) + three non-labelled pots (blank) for each treatment) were randomly placed in a growth chamber ( $14 \mathrm{~h}$ daytime period, light intensity $800 \mu \mathrm{mol} \mathrm{m}^{-2} \mathrm{~s}^{-1}$, with daytime and nighttime temperatures of $25^{\circ} \mathrm{C}$ and $20^{\circ} \mathrm{C}$ respectively). After two months growth, pots were transferred to the gas-tight system for pulse labelling (figure 1). Owing to the negative impacts of petroleum pollution on plant biomass (table 1), the upper chambers were designed at different heights, and thus created volumes of 875,625 and $375 \mathrm{~cm}^{3}$ (the same basal area, $25 \mathrm{~cm}^{2}$ ), which were used to label plants growing in control, low-polluted and high-polluted soils, respectively. After $\mathrm{CO}_{2}$ concentrations fell to about $200 \mathrm{ppm}(\mathrm{v} / \mathrm{v})$ in the upper chambers, three pulses of ${ }^{13} \mathrm{CO}_{2}$ at an interval of $2 \mathrm{~h}$ were applied from $9.00 \mathrm{~h}$ to $15.00 \mathrm{~h}$ (figure 1). Each pulse contained $400 \mathrm{ppm}$ of ${ }^{13} \mathrm{CO}_{2}(\mathrm{v} / \mathrm{v})$ by mixing $1 \mathrm{ml}$ of lactic acid $(1.5 \mathrm{M})$ and $1 \mathrm{ml}$ of $\mathrm{NaH}^{13} \mathrm{CO}_{3}$ solution (different contents according to the upper chambers' volumes; greater than 99 atom\%, Cambridge Isotope Laboratories; Butler et al. 2004)

Soils and plants were sampled at 24 and $72 \mathrm{~h}$ after the initiation of pulse-labelling. $\mathrm{C}$ and ${ }^{13} \mathrm{C}$ contents in plant tissues, soils and microbial biomass (MBC) were determined by a mass spectrometer (MAT 253, Finnigan, Germany) coupled with an elemental analyser (FlashEA 1112, Finnigan, Italy; Bardgett et al. 2003). $\mathrm{CO}_{2}$ captured in an $\mathrm{NaOH}$ solution was quantified by titration, and then the solutions were freeze-dried for analysing ${ }^{13} \mathrm{C}$ content through evolving $\mathrm{CO}_{2}$ by adding phosphoric acid in a Gasbench II Device (Finnigan; Landi et al. 2003). All ${ }^{13} \mathrm{C}$ data were corrected from average values of blanks. The total ${ }^{13} \mathrm{C}$ recovery expressed as the proportion of total assimilated ${ }^{13} \mathrm{C}$ in total supplied ${ }^{13} \mathrm{C}$ (Fan et al. 2008).

The effects of petroleum concentration on plant biomass and total recovery of ${ }^{13} \mathrm{C}$ were examined using one-way ANOVA. The effects of petroleum concentration and incubation time on the ${ }^{13} \mathrm{C}$ proportions in the total assimilated ${ }^{13} \mathrm{C}$ in plant biomass, soil, soil respiration and MBC were examined using two-way ANOVA. 


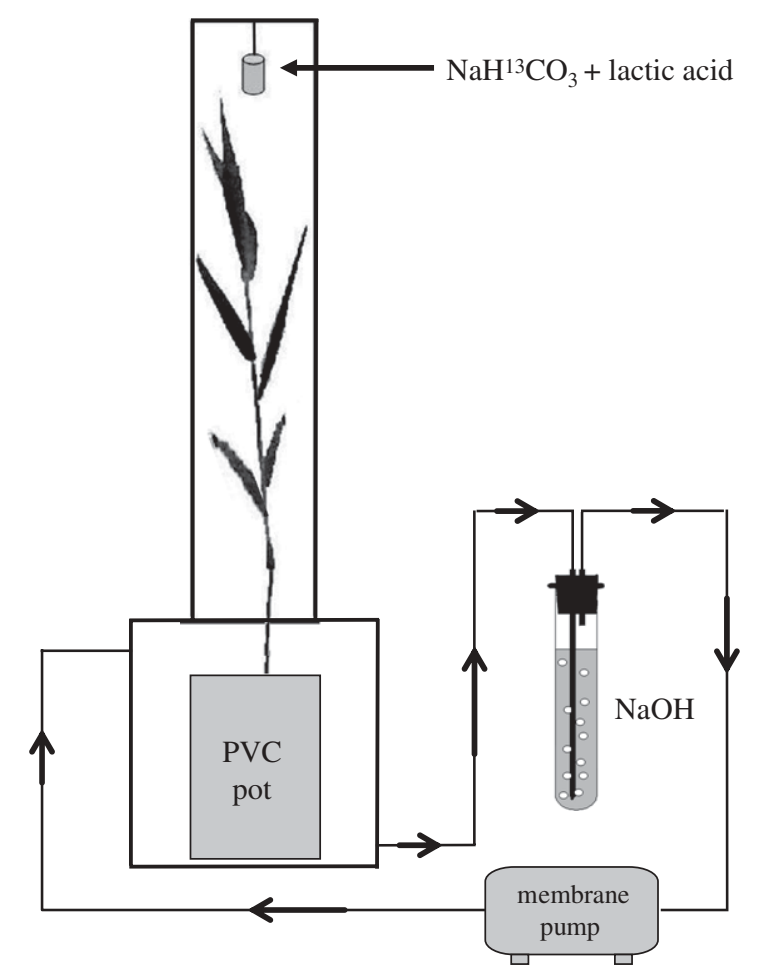

Figure 1. Sketch of experimental set-up used in this study. The gas-tight system consisted of independent upper and bottom chambers made from Plexiglas, and an installation for capturing soil respiration $\mathrm{CO}_{2}$.

\section{RESULTS}

\section{(a) Plant biomass and recovery of ${ }^{13} \mathrm{C}$}

Plant shoot $(F=352.59, \quad p<0.001)$ and root $(F=98.31, \quad p<0.001) \quad$ biomass significantly decreased as petroleum concentration increased. However, the root-shoot ratio $(F=11.65, p<0.001)$ significantly increased with increasing petroleum concentration (table 1). The total recovery of ${ }^{13} \mathrm{C}$ did not vary significantly among treatments $(F=0.054$, $p=0.948 ;$ table 1 ).

\section{(b) ${ }^{13}$ C allocation to plant biomass}

The ${ }^{13} \mathrm{C}$ proportion in plant shoots expressed as the percentage of shoot ${ }^{13} \mathrm{C}$ in the total assimilated ${ }^{13} \mathrm{C}$ was significantly affected by petroleum concentration (table 2), and the ${ }^{13} \mathrm{C}$ allocation to plant shoots decreased as petroleum concentration increased at both $24(71-48 \%)$ and $72 \mathrm{~h}(69-29 \%$ ) (figure $2 a$ ). Although incubation time did not significantly affect the ${ }^{13} \mathrm{C}$ proportion in plant shoots (table 2), the decrease in the ${ }^{13} \mathrm{C}$ proportion at $72 \mathrm{~h}$ relative to that at $24 \mathrm{~h}$ increased as petroleum concentration increased, i.e. control $(-2 \%)$, low pollution $(-4 \%)$, high pollution $(-19 \%)$. Although petroleum concentration and incubation time did not significantly affect the ${ }^{13} \mathrm{C}$ proportion in plant roots (table 2, figure $2 b$ ), the root-shoot ratio of ${ }^{13} \mathrm{C}$ was significantly influenced by petroleum concentration and its interaction with incubation time (table 2). The root-shoot ratio of ${ }^{13} \mathrm{C}$ increased as petroleum concentration increased at both $24(0.36-0.64)$ and $72 \mathrm{~h}(0.33-1.12)$ (figure $2 c$ ).

\section{(c) ${ }^{13} \mathrm{C}$ allocation in soil and respiration}

Petroleum pollution and incubation time had significant effects on the total soil ${ }^{13} \mathrm{C}$ proportion (table 2), and petroleum pollution increased ${ }^{13} \mathrm{C}$ allocation to the soil at both 24 and $72 \mathrm{~h}$ (figure $2 d$ ). The ${ }^{13} \mathrm{C}$ proportion in $\mathrm{MBC}$ was quite similar to the total soil ${ }^{13} \mathrm{C}$ proportion in response to petroleum pollution and incubation time (table 2 and figure $2 e$ ). Petroleum pollution also had significant effects on the ${ }^{13} \mathrm{C}$ proportion in soil ${ }^{13} \mathrm{C}-\mathrm{CO}_{2}$ respiration (table 2), which sharply increased with increasing petroleum concentration within $24 \mathrm{~h}(3-17 \%)$. At $72 \mathrm{~h}$, a high ${ }^{13} \mathrm{C}$ proportion in soil ${ }^{13} \mathrm{C}-\mathrm{CO}_{2}$ respiration occurred in high-polluted soil (33\%) but not in control $(6 \%)$ and low-polluted soils (9\%) (figure $2 f$ ).

\section{DISCUSSION}

Phragmites australis biomass significantly decreased under petroleum pollution, but the root-shoot ratio both in plant biomass and ${ }^{13} \mathrm{C}$ increased with increasing petroleum concentration. Furthermore, assimilated ${ }^{13} \mathrm{C}$ was found to be higher in soil, MBC and soil respiration after soils were polluted by petroleum. These results suggested that plants increased biomass allocation to its belowground parts, and carbon released from roots is rapidly turned over by soil microbes under petroleum pollution.

Being similar to the previous studies (Butler et al. 2004; Fan et al. 2008), the total ${ }^{13} \mathrm{C}$ recoveries in this study ranged between 50 and 58 per cent (table 1). There was no significant difference in the ${ }^{13} \mathrm{C}$ recovery among treatments from the same initial ${ }^{13} \mathrm{CO}_{2}$ content (table 1); therefore our gas-tight system with different sizes of upper chambers was suitable for studying ${ }^{13} \mathrm{C}$ allocation of plants under petroleum pollution.

In this study, we found that the root-shoot ratio in both biomass and ${ }^{13} \mathrm{C}$ positively responded to petroleum pollution (tables 1,2 and figure $2 c$ ), indicating that $P$. australis could allocate more biomass to roots in response to petroleum pollution. High ${ }^{13} \mathrm{C}$ proportions in soil, $\mathrm{MBC}$ and respiration were also found in this study (figure 2), indicating that plants released a high proportion of biomass as root exudates to petroleumpolluted soils (Fan et al. 2008). Thus petroleum pollution appeared to not only promote the carbon allocation to plant roots but also enhanced the release of carbon from roots. These results provide evidence that plant biomass allocation also has profound effects on soil processes and microbial activities (Hogberg et al. 2001; Hogberg \& Read 2006).

High ${ }^{13} \mathrm{C}$ proportions in $\mathrm{MBC}$ and soil respiration also indicated that rapid turnover of soil resources occurred in petroleum-polluted soils (figure 2e,f) (Zhou \& Crawford 1995; Caravaca \& Roldan 2003). Furthermore, petroleum concentration had a greater effect than incubation time on the proportions of ${ }^{13} \mathrm{C}$ in plants, soil, MBC and soil respiration (table 2), suggesting that transfer of the photosynthetically fixed carbon from shoots to the roots and into the soil was mainly petroleum-dependent and fast. These observations are consistent with the previous reports about rapid turnover of photosynthetically fixed 

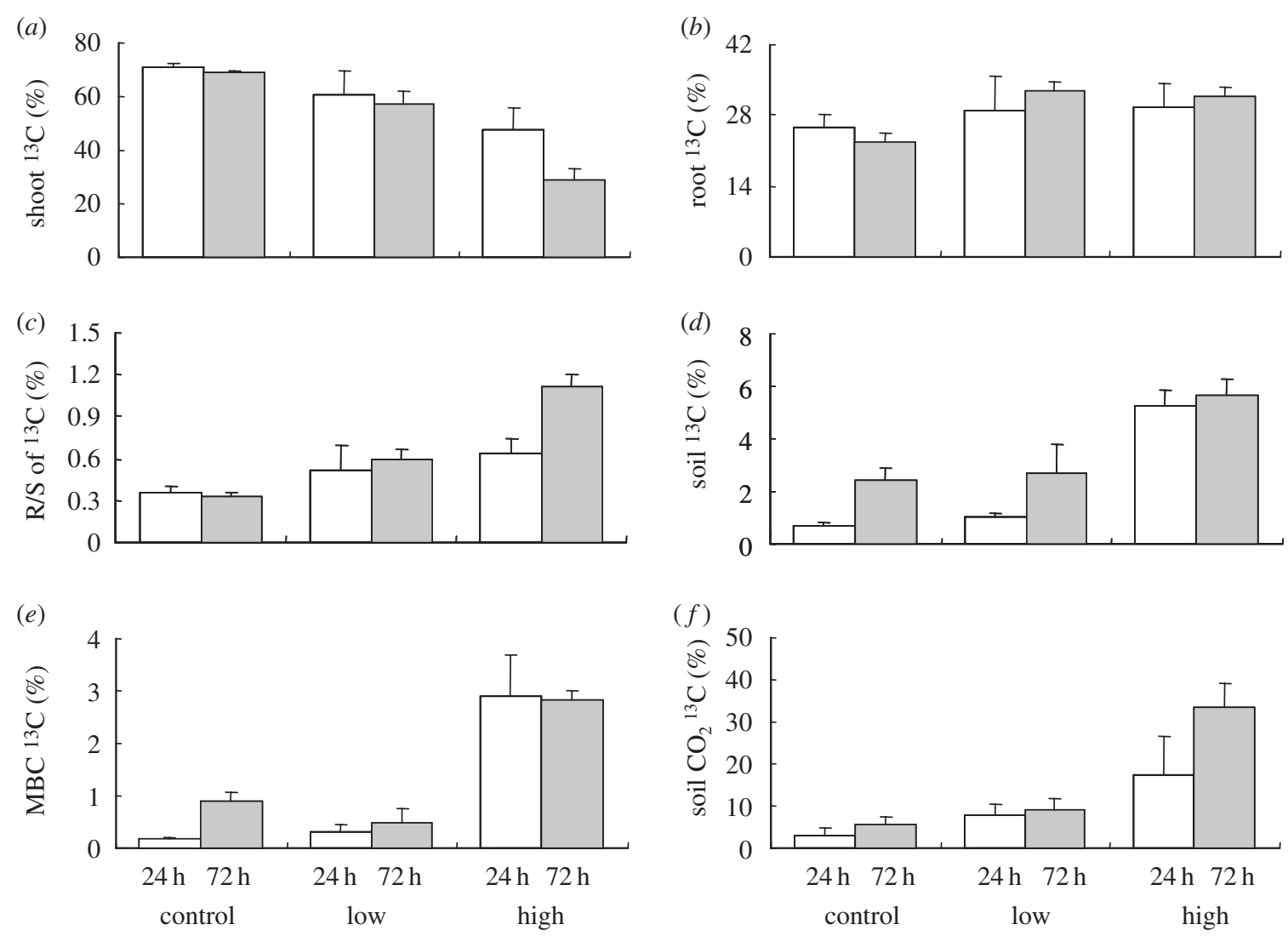

Figure 2. The proportions of total assimilated ${ }^{13} \mathrm{C}$ in $(a)$ plant shoots, $(b)$ roots, $(c)$ the root-shoot $(\mathrm{R} / \mathrm{S})$ ratio of assimilated ${ }^{13} \mathrm{C},(d)$ total soil carbon, (e) microbial biomass carbon $(\mathrm{MBC})$ and $(f)$ soil respiration $\left(\mathrm{CO}_{2}\right)$ at different petroleum concentrations after being incubated for 24 and $72 \mathrm{~h}$. Values are means \pm s.e.

Table 1. Plant shoot and root biomass (dry weight), the root-shoot ratios and the ${ }^{13} \mathrm{C}$ recoveries (expressed as the proportion of total supplied ${ }^{13} \mathrm{C}$ ) at different petroleum concentrations. (Values are means \pm s.e. The same letters denote non-significant differences between treatments $(p>0.05)$.)

\begin{tabular}{lllll}
\hline & shoot biomass $(\mathrm{g})$ & root biomass $(\mathrm{g})$ & root-shoot & ${ }^{13} \mathrm{C}$ recovery $(\%)$ \\
\hline control & $0.194 \pm 0.011^{\mathrm{a}}$ & $0.071 \pm 0.007^{\mathrm{a}}$ & $0.364 \pm 0.033^{\mathrm{c}}$ & $52 \pm 7^{\mathrm{a}}$ \\
low & $0.051 \pm 0.002^{\mathrm{b}}$ & $0.024 \pm 0.002^{\mathrm{b}}$ & $0.462 \pm 0.022^{\mathrm{b}}$ & $58 \pm 10^{\mathrm{a}}$ \\
high & $0.023 \pm 0.002^{\mathrm{c}}$ & $0.015 \pm 0.001^{\mathrm{c}}$ & $0.671 \pm 0.071^{\mathrm{a}}$ & $50 \pm 7^{\mathrm{a}}$ \\
\hline
\end{tabular}

Table 2. Summary of two-way ANOVAs to test the effects of petroleum pollution and incubation time on the ${ }^{13} \mathrm{C}$ proportions of total assimilated ${ }^{13} \mathrm{C}$ in plant biomass, soil, microbial biomass (MBC) and soil respiration.

\begin{tabular}{llrl}
\hline variables & source of variation & $F$ & $p$ \\
\hline shoot ${ }^{13} \mathrm{C}$ proportion & petroleum & 16.593 & $p<0.001$ \\
& time & 3.172 & 0.100 \\
root ${ }^{13} \mathrm{C}$ proportion & petroleum $\times$ time & 1.405 & 0.283 \\
& petroleum & 2.232 & 0.150 \\
& time & 0.145 & 0.710 \\
root $/$ shoot of ${ }^{13} \mathrm{C}$ & petroleum $\times$ time & 0.504 & 0.616 \\
& petroleum & 15.797 & $p<0.001$ \\
soil ${ }^{13} \mathrm{C}$ proportion & time & 4.715 & 0.051 \\
& petroleum $\times$ time & 3.974 & $p<0.05$ \\
MBC ${ }^{13} \mathrm{C}$ proportion & petroleum & 23.933 & $p<0.001$ \\
& time & 14.175 & $p<0.01$ \\
soil CO ${ }_{2}^{13} \mathrm{C}$ proportion & petroleum $\times$ time & 3.557 & 0.061 \\
& petroleum & 21.260 & $p<0.001$ \\
& time & 5.012 & $p<0.05$ \\
& petroleum $\times$ time & 2.230 & 0.150 \\
& petroleum & 10.732 & $p<0.01$ \\
& time & 2.087 & 0.174 \\
& petroleum $\times$ time & 1.936 & 0.187 \\
\hline
\end{tabular}


carbon (Butler et al. 2004; Kastovska \& Santruckova 2007).

In conclusion, our study suggests that plants, in response to petroleum pollution, increase biomass allocation to their belowground parts, and carbon released from roots is rapidly turned over by soil microbes. Our observed responses of plants to petroleum pollution are similar to those other belowground stresses (Nguyen 2003; Jones et al. 2004; Paterson et al. 2009). Therefore, this study suggested that plants can modulate biomass allocation in response to petroleum pollution.

This work was supported by the National Basic Research Programme of China (grant no. 2006CB403 305) to B.L., and the Innovative Foundation of graduate students of Fudan University (grant no. EYH1322131).

Bardgett, R. D., Streeter, T. C. \& Bol, R. 2003 Soil microbes compete effectively with plants for organic-nitrogen inputs to temperate grasslands. Ecology 84, 1277-1287. (doi:10.1890/0012-9658(2003)084)

Berendse, F. \& Moller, F. 2009 Effects of competition on root-shoot allocation in Plantago lanceolata L.: adaptive plasticity or ontogenetic drift? Plant Ecol. 201, 567-573. (doi: 10.1007/s11258-008-9485-z)

Bonifas, K. D., Walters, D. T., Cassman, K. G. \& Lindquist, J. L. 2005 Nitrogen supply affects root : shoot ratio in corn and velvetleaf (Abutilon theophrasti). Weed Sci. 53, 670-675. (doi:10.1614/WS-05-002R.1)

Butler, J. L., Bottomley, P. J., Griffith, S. M. \& Myrold, D. D. 2004 Distribution and turnover of recently fixed photosynthate in ryegrass rhizospheres. Soil Biol. Biochem. 36, 371-382. (doi:10.1016/j.soilbio.2003.10.011)

Caravaca, F. \& Roldan, A. 2003 Assessing changes in physical and biological properties in a soil contaminated by oil sludges under semiarid Mediterranean conditions. Geoderma 117, 53-61. (doi:10.1016/S00167061(03)00118-6)

Culbertson, J. B., Valiela, I., Pickart, M., Peacock, E. E. \& Reddy, C. M. 2008 Long-term consequences of residual petroleum on salt marsh grass. F. Appl. Ecol. 45, 1284-1292. (doi:10.1111/j.1365-2664.2008.01477.x)

Dowty, R. A., Shaffer, G. P., Hester, M. W., Childers, G. W., Campo, F. M. \& Greene, M. C. 2001 Phytoremediation of small-scale oil spills in fresh marsh environments: a mesocosm simulation. Mar. Environ. Res. 52, 195-211. (doi:10.1016/S0141-1136(00)00268-3)

Engloner, A. I. 2009 Structure, growth dynamics and biomass of reed (Phragmites australis): a review. Flora 204, 331-346. (doi:10.1016/j.flora.2008.05.001)

Fan, F. L., Zhang, F. S., Qu, Z. \& Lu, Y. H. 2008 Plant carbon partitioning below ground in the presence of different neighboring species. Soil Biol. Biochem. 40, 2266-2272. (doi:10.1016/j.soilbio.2008.05.003)

Hermans, C., Hammond, J. P., White, P. J. \& Verbruggen, N. 2006 How do plants respond to nutrient shortage by biomass allocation? Trends Plant Sci. 11, 610-617. (doi:10.1016/j.tplants.2006.10.007)

Hogberg, P. \& Read, D. J. 2006 Towards a more plant physiological perspective on soil ecology. Trends Ecol. Evol. 21, 548-554. (doi:10.1016/j.tree.2006.06.004)

Hogberg, P., Nordgren, A., Buchmann, N., Taylor, A. F. S., Ekblad, A., Högberg, M. N., Nyberg, G., OttossonLöfvenius, M. \& Read, D. J. 2001 Large-scale forest girdling shows that current photosynthesis drives soil respiration. Nature 411, 789-792. (doi:10.1038/ 35081058)

Jones, D. L., Hodge, A. \& Kuzyakov, Y. 2004 Plant and mycorrhizal regulation of rhizodeposition. New Phytol. 163, 459-480. (doi:10.1111/j.1469-8137.2004. 01130.x)

Kastovska, E. \& Santruckova, H. 2007 Fate and dynamics of recently fixed $C$ in pasture plant-soil system under field conditions. Plant Soil 300, 61-69. (doi:10.1007/s11104007-9388-0)

Kingston, P. F. 2002 Long-term environmental impact of oil spills. Spill Sci. Technol. Bull. 7, 53-61. (doi:10.1016/ S1353-2561(02)00051-8)

Kuzyakov, Y., Kretzschmar, A. \& Stahr, K. 1999 Contribution of Lolium perenne rhizodeposition to carbon turnover of pasture soil. Plant Soil 213, 127-136. (doi:10.1023/A:1004566027237)

Landi, A., Mermut, A. R. \& Anderson, D. W. 2003 Origin and rate of pedogenic carbonate accumulation in Saskatchewan soils, Canada. Geoderma 117, 143-156. (doi:10.1016/S0016-7061(03)00161-7)

Liu, W. X., Luo, Y. M., Teng, Y., Li, Z. G. \& Wu, L. H. 2007 A survey of petroleum contamination in several Chinese oilfield soils. Soils $39,247-251$.

Mahoney, K. J. \& Swanton, C. J. 2008 Nitrogen and light affect the adaptive traits of common lambsquarters (Chenopodium album). Weed Sci. 56, 81-90. (doi:10. 1614/WS-07-086.1)

Nguyen, C. 2003 Rhizodeposition of organic C by plants: mechanisms and controls. Agronomie 23, 375-396. (doi:10.1007/978-90-481-2666-8)

Nie, M., Zhang, X. D., Wang, J. Q., Jiang, L. F., Yang, J., Quan, Z. X., Cui, X. H., Fang, C. M. \& Li, B. 2009 Rhizosphere effects on soil bacterial abundance and diversity in the Yellow River Deltaic ecosystem as influenced by petroleum contamination and soil salinization. Soil Biol. Biochem. 41, 2535-2542. (doi:10.1016/j.soilbio.2009. 09.012)

Paterson, E., Midwood, A. J. \& Millard, P. 2009 Through the eye of the needle: a review of isotope approaches to quantify microbial processes mediating soil carbon balance. New Phytol. 184, 19-33. (doi:10.1111/j.1469-8137. 2009.03001.x)

Peterson, C. H., Rice, S. D., Short, J. W., Esler, D., Bodkin, J. L., Ballachey, B. E. \& Irons, D. B. 2003 Long-term ecosystem response to the Exxon Valdez oil spill. Science 302, 2082-2086. (doi:10.1126/science.1084282)

Zhou, E. \& Crawford, R. L. 1995 Effects of oxygen, nitrogen, and temperature on gasoline biodegradation in soil. Biodegradation 6, 127-140. (doi:10.1007/BF00 695343) 